\title{
KAJIAN HUKUM TERHADAP PERANGKAT DESA YANG IKUT SERTA DALAM KAMPANYE PEMILU DI KABUPATEN INDRAGIRI HILIR
}

\author{
Fitri Wahyuni ${ }^{1}$, Aris Irawan ${ }^{2}$, \\ ${ }^{1}$ Prodi Ilmu Hukum, Fakultas Hukum, Universitas Islam Indragiri \\ 2 Prodi Magister Hukum, Fakultas Hukum, Universitas Borneo Tarakan \\ Email: fw160586@gmail.com (korespondensi)
}

\begin{abstract}
The general election or regional head election (hereinafter referred to as the Regional Head Election) in a country is an effort to realize good governance and the realization of a democratic state. However, it raises legal problems in the field, such as the occurrence of the attitudes of state officials or state apparatus in this case, one of which is village officials who participate in efforts to win one of the candidates for election and post-conflict local election. This needs to be investigated through legal studies using normative legal research methods, with legal research sources namely primary legal materials and secondary legal materials and the analysis used in this study using qualitative analysis. The Village Head is one part of the Government Bureaucracy which has been clearly regulated in the Election Law. All government bureaucracies may not be involved or support one candidate, including one of them is the Village Head, but in practice there are still many Village Heads who support certain candidates. In article 66 clause 2 part $C$ about The General Election Commission Regulation Number 7 of 2015 was emphasized in the campaign, candidate pairs and/or campaign teams are prohibited from involving "village head or other designations/lurah and village apparatus or other designations/kelurahan." The prohibition to include village heads and village apparatus is contained in Article 280 paragraph (2) of the Election Law. It is clear that if the campaign involves the village apparatus, it is included in the election violation and is included in an election crime and can be given a criminal sanction if it is proven to have committed an election crime.
\end{abstract}

Keywords: Election, Campaign, Law

\begin{abstract}
Abstrak
Pemilihan umum ataupun juga pemilihan kepala daerah (yang selanjutnya disebut dengan Pemilukada) dalam suatu negara merupakan upaya untuk mewujudkan pemerintahan yang baik serta terwujudnya negara demokrasi. Namun menimbulkan persoalan-persoalah hukum di lapangan seperti terjadinya sikap-sikap aparat negara atau perangkat-perangkat negara dalam hal ini salah satunya adalah perangkat desa yang ikut serta dalam upaya memenangkan salah satu calon peserta pemilu maupun pemilukada. Hal ini perlu diteliti melalui kajian hukum dengan metode penelitian hukum normatif, dengan sumber penelitian hukum yakni bahan hukum primer dan bahan hukum sekunder serta analisa yang digunakan dalam penelitian ini dengan menggunakan analisis kualitatif. Kepala Desa merupakan salah satu bagian dari Birokrasi Pemerintah yang telah diatur secara jelas di dalam UndangUndang Pemilu. Semua birokrasi pemerintahan tidak boleh terlibat ataupun mendukung salah satu calon termasuk salah satunya adalah Kepala Desa namun dalam pelaksanaannya masih banyak seorang Kepala Desa menjadi pendukung bagi calon tertentu. Pada pasal 66 ayat 2 bagian C Peraturan Komisi Pemilihan Umum Nomor 7 tahun 2015 ditegaskan dalam kampanye, pasangan calon dan/atau tim kampanye dilarang melibatkan "kepala desa atau sebutan lain/lurah dan perangkat desa atau sebutan lain/kelurahan "Larangan mengikut sertakan kepala desa dan perangkat desa terdapat dalam Pasal 280 ayat (2) Undang-Undang Pemilu. Jelas bahwa apabila dalam kampanye melibatkan dan perangkat desa termasuk dalam pelanggaran pemilu dan masuk dalam tindak pidana pemilu dan dapat diberi sanksi berupa pidana apabila terbukti melakukan tindak pidana pemilu.
\end{abstract}

Kata kunci: Pemilihan Umum, Kampanye, Hukum 


\section{PENDAhUlUAN}

Pemilihan Umum atau Pemilu merupakan pesta demokrasi yang harus diselenggarakan oleh negara demokrasi. Indonesia sebagai negara demokrasi telah melaksanakan Pemilu sebagai kegiatan rutin yang diadakan setiap lima tahun sekali. Pelaksanaan Pemilu di Indonesia selalu diikuti dengan pembuatan instrumen hukum tentang Pemilu. Pemilu pada hakikatnya merupakan sarana pemenuhan demokrasi dari suatu negara, yaitu perwujudan dari asas kedaulatan rakyat sebagaimana rumusan negara Pasal 1 ayat (2) UndangUndang Republik Indonesia Tahun 1945. Menurut ketentuan Pasal 1 butir 1 UndangUndang Republik Indonesia No. 7 Tahun 2017 Tentang Pemilihan Umum adalah sarana kedaulatan rakyat untuk memilih anggota Dewan Perwakilan Rakyat, anggota Dewan Perwakilan Rakyat, Presiden dan wakil Presiden, dan untuk memilih Anggota Dewan Perwakilan Rakyat Daerah, yang dilaksanakan secara langsung , umum, bebas, rahasia, jujur, dan adil dalam Negara Kesatuan Republik Indonesia. Sebagai sarana pelaksanaan kedaulatan rakyat, pemilihan umum (pemilu) pasca perubahan Undang-Undang Dasar Negara Republik Indonesia Tahun 1945 mengalami perkembangan yang amat pesat. Hal itu ditandai dengan tingginya tingkat kebutuhan akan aturan pemilu dan banyaknya jenis pemilu yang mesti dilaksanakan dalam satu periode pemerintahan. Hanya saja, perkembangan tersebut juga membawa dampak terhadap munculnya kompleksitas. Setidaknya, perkembangan dunia pemilu Indonesia diwarnai dengan: kerawanan disharmoni dan ketidakpastian aturan, ketegangan antar institusi yang terlibat dalam penyelenggaraan, dan ketidakpastian proses penegakan hukum dan penyelesaian sengketa pemilu. Akibatnya, setiap tahapan pemilu atau pilkada akan dilaksanakan, nyaris selalu diwarnai keriuhan.

Salah satu persoalan yang muncul yaitu berkaitan dengan kampanye menjelang diadakannya pemiilihan umum atau pemilihan kepala daerah. Kampanye merupakan sarana yang dilakukan para calon anggota legislatif untuk memperkenalkan diri mereka agar dikenal oleh masyarakat sehingga para calon anggota legisltaif dapat dipilih pada pemilu yang sudah dijadwalkan. Secara teoritik, kampanye adalah kegiatan yang terorganisasi dan sistematis dalam rangka mendorong masyarakat melakukan suatu yang diinginkan dengan memanfaatkan metode dan media tertentu. Dengan demikian, dalam kontek pemilu, kampanye adalah kegiatan peserta pemilu untuk mendorong masyarakat agar berpihak kepada peserta pemilu yang melakukan kampanye. Namun dalam praktik dilapangan ditemukan adanya penyimpangan terhadap pelaksanaan kampanye yang berujung kepada ketidaknetralan, dimana pejabat negara ikut serta dalam mengkampanyekan seorang calon tertentu sehingga memenangkan calon tertentu dalam pemilu legislatif maupun pemilihan kepada daerah tersebut.

Undang-Undang Nomor 10 Tahun 2016 tentang Perubahan Kedua Atas UndangUndang Nomor 1 Tahun 2015 Tentang Penetapan Peraturan Pemerintah Nomor 1 Tahun 2014 Tentang Pemilihan Gubernur, Bupati dan Walikota Menjadi UndangUndang. a. Pasal 70 ayat 1 huruf b Pasangan calon dilarang melibatkan Aparatur Sipil Negara, Anggota Kepolisian Negara Republik Indonesia dan Anggota Tentara Nasional Indonesia. b. Pasal 70 ayat 1 huruf c Pasangan calon dilarang melibatkan kepala desa atau sebutan lain/lurah dan perangkat desa atau sebutan lain/perangkat kelurahan. Di dalam Undang-Undang Pemilu pada ketentuan Pasal 188 Undang -Undang Nomor 10 tahun 2016 yang berbunyi "Setiap pejabat negara, pejabat Aparatur Sipil Negara, dan Kepala Desa atau sebutan lain/Lurah yang dengan sengaja melanggar ketentuan sebagaimana dimaksud dalam Pasal 71, dipidana dengan pidana penjara paling singkat 1 (satu) bulan atau paling lama 6 (enam) bulan dan/atau denda paling sedikit Rp600.000,00 (enam ratus ribu rupiah) atau paling banyak Rp6.000.000,00 (enam juta rupiah)" kemudian dapat di uraikan bahwa di dalam Pasal 71, (1) di jelaskan bahwa Pejabat negara, pejabat daerah, pejabat aparatur sipil negara, anggota TNI/POLRI, dan Kepala Desa atau sebutan lain/Lurah dilarang membuat keputusan dan/atau tindakan yang menguntungkan atau merugikan salah satu pasangan calon.

Dari dua ketentuan diatas sangat jelas bahwa seorang Kepala Desa tidak dibolehkan melanggar ketentuan Pidana pemilihan tersebut yang di ikuti dengan sanksi pidana yang jelas di dalam UndangUndang Nomor 10 tahun 2016 tersebut. Begitu juga dalam hal pemilihan umum Kabupaten Indragiri Hilir yang terdiri dari 20 kecamatan 236 desa, potensi ini menjadi sangat mungkin karna tidak ada penghalang secara langsung yang menjadikan berpotensi masing-masing Kepala Desa 
mendapat tarik ulur pengaruh politik dari berbagai pasangan calon dan calon Legislatif dan berbagai kepentingan politik. Perlu kajian yang menyeluruh terkait potensi yang besar terjadinya pelanggaran baik secara administratif maupun pidana terkait Kepala Desa sebagai bagian dari subjek yang diatur di dalam perundang-undangan pemilihan umum maupun pemilihan kepala daerah.

Dengan banyaknya jumlah desa tersebut di Kabupaten Indragiri Hilir, menjadi kan potensi konflik kepentingan di dalam pemilu maupun terutama di dalam pemilihan kepala daerah menjadi sangat mungkin karena sangat logis seseorang akan memenangkan kontestasi politik di pemilihan kepala daera misalnya dengan mempengaruhi sebanyakbanyaknya kepala desa beserta perangkatperangkatnya untuk menguntungkannya atau berpihak terhadap salah satu pasangan calon.

Terbukti khusus untuk pemilihan kepala daera di Kabupaten Indragiri Hilir menjadikan desa sebagai tolak ukur suksesnya Pilkada karena struktur dan juga kultur desa yang homogen sehingga sangat mudah dipengaruhi dalam kontestasi politik. Dengan cara mempengaruhi kepala desa dan perangkatnya sehingga pasangan calon dan tim sukses dapat mendapatkan suara masayarakatnya.

Sehingga potensi-potensi ini dikaitkan dengan ketentuan-ketentuan peraturan perundang-undangan yang ada diharapkan akan menjadi informasi pendidikan politik bagi para kepala desa di Kabupaten Indragiri Hilir agar terhindar dari perbuatanperbuatan yang melanggar ketentuan undang-undang yang memiliki sanksi administratif secara langsung terhadap kelangsungan jabatan kepala desanya termasuk ancaman sanksi pidana pemilihan baik dalam pemilihan umum maupun pemilihan kepala daerah.

\section{TINJAUAN PUSTAKA}

\subsection{Landasan Yuridis Tentang Kenetralan Pejabat Pemerintah/Negara dalam Kampanye Pemilu}

Netralitas merupakan salah satu asas yang penting dalam penyelenggaraan tugas pelayanan publik, tugas pemerintahan dan tugas pembangunan. Setiap pegawai ASN maupun pejabat pemerintah/negara harus bersikap netral untuk dapat menjalankan tugasnya secara professional. Untuk menegakkan netralitas ASN, pejabat pemerintah/ negara, pemerintah telah mengeluarkan sejumlah peraturan perundangundangan. Namun demikian, tingkat pelanggaran terhadap azas netralitas di kalangan
ASN, pejabat pemerintah/ negara masih tinggi, terutama menjelang pelaksanaan pemilu dan Pilkada serentak. Sementara itu, ketidaknetralan pegawai ASN, pejabat pemerintah/ negara dapat menyebabkan terjadinya keberpihakan atau ketidakadilan dalam pembuatan kebijakan dan penyelenggaraan pelayanan yang pada akhirnya akan menimbulkan kerugian bagi masyarakat secara luas.

Netralitas menurut Kamus Besar Bahasa Indonesia (KBBI) adalah keadaan dan sikap netral, dalam arti tidak memihak, atau bebas. Menurut Nuraida Mokhsen netralitas ASN mengandung makna impartiality yaitu bebas kepentingan, bebas intervensi, bebas pengaruh, adil, objektif, dan tidak memihak. Sementara itu Marbun dalam Sri Hartini menyampaikan bahwa netralitas adalah bebasnya Pegawai Negeri Sipil dari pengaruh kepentingan partai politik tertentu atau tidak memihak untuk kepentingan partai politik tertentu atau tidak berperan dalam proses politik.(Harry Setiawan 2013)

Netralitas menurut Kamus Besar Bahasa Indonesia (KBBI) adalah keadaan dan sikap netral, dalam arti tidak memihak, atau bebas. Menurut Nuraida Mokhsen netralitas ASN mengandung makna impartiality yaitu bebas kepentingan, bebas intervensi, bebas pengaruh, adil, objektif, dan tidak memihak . Sementara itu Marbun dalam Sri Hartini menyampaikan bahwa netralitas adalah bebasnya Pegawai Negeri Sipil dari pengaruh kepentingan partai politik tertentu atau tidak memihak untuk kepentingan partai politik tertentu atau tidak berperan dalam proses politik.(Ii 2012) Apabila dikaitkan dengan penyelenggaraan pemilu ataupun Pilkada, netralitas dapat didefenisikan sebagai perilaku tidak memihak, atau tidak terlibat yang ditunjukan birokrasi pemerintahan dalam masa kampanye kandidat kepala daerah di ajang pemilukada baik secara diam-diam maupun terang-terangan. Menurut La Ode Muh. Yamin, ada dua indikator utama dari netralitas politik, yaitu: (1) Tidak terlibat, dalam arti tidak menjadi tim sukses calon kandidat pada masa kampanye atau menjadi peserta kampanye baik dengan menggunakan atribut partai atau atribut PNS. (2) Tidak memihak, dalam arti tidak membantu dalam membuat keputusan dan/atau tindakan yang menguntungkan salah satu pasangan calon, tidak mengadakan kegiatan yang mengarah kepada keberpihakan terhadap salah satu pasangan calon Kepala Daerah/Wakil Kepala Daerah pada masa kampanye meliputi pertemuan, ajakan, himbauan, seruan, atau pemberian barang kepada PNS dalam lingkup unit kerjanya, anggota keluarga, dan masyarakat, serta tidak membantu dalam menggunakan fasilitas negara yang terkait dengan jabatan dalam rangka pemenangan salah satu calon pasangan Kepala Daerah/Wakil Kepala Daerah pada masa kampanye. 
Undang Undang Nomor 5 Tahun 2014 Tentang Aparatur Sipil Negara (ASN) a. Pasal 2 huruf $f$, menyatakan bahwa salah satu asas penyelenggaraan kebijakan dan manajemen ASN adalah "Netralitas". Asas Netralitas ini berarti bahwa setiap pegawai ASN tidak berpihak dari segala bentuk pengaruh manapun dan tidak memihak kepada kepentingan siapapun. b. Pasal 87 ayat 4 huruf b, menyatakan bahwa PNS diberhentikan dengan tidak hormat karena menjadi anggota dan/atau pengurus partai politik. c. Pasal 119 dan Pasal 123 ayat 3, berdasarkan putusan Mahkamah Konstitusi Nomor 41/PUU-XIII/2014 Tanggal 6 Juli 2015, "PNS yang mencalonkan diri atau dicalonkan menjadi Gubernur/Wakil Gubernur, Bupati/Wakil Bupati, Walikota/Wakil Walikota wajib menyatakan pengunduran diri secara tertulis sebagai PNS sejak ditetapkan sebagai calon peserta pemilihan Gubernur/Wakil Gubernur, Bupati/Wakil Bupati, Walikota/Wakil Walikota" PNS yang tidak melaksanakan ketentuan tersebut dijatuhi sanksi hukuman disiplin.

Undang-Undang Nomor 10 Tahun 2016 tentang Perubahan Kedua Atas Undang- Undang Nomor 1 Tahun 2015 Tentang Penetapan Peraturan Pemerintah Nomor 1 Tahun 2014 Tentang Pemilihan Gubernur, Bupati dan Walikota Menjadi Undang- Undang. a. Pasal 70 ayat 1 huruf $b$ Pasangan calon dilarang melibatkan Aparatur Sipil Negara, Anggota Kepolisian Negara Republik Indonesia dan Anggota Tentara Nasional Indonesia. b. Pasal 70 ayat 1 huruf $\mathrm{c}$ Pasangan calon dilarang melibatkan kepala desa atau sebutan lain/lurah dan perangkat desa atau sebutan lain/perangkat kelurahan.

Di dalam Undang-Undang Pemilu pada ketentuan Pasal 188 Undang - Undang Nomor 10 tahun 2016 yang berbunyi "Setiap pejabat negara, pejabat Aparatur Sipil Negara, dan Kepala Desa atau sebutan lain/Lurah yang dengan sengaja melanggar ketentuan sebagaimana dimaksud dalam Pasal 71, dipidana dengan pidana penjara paling singkat 1 (satu) bulan atau paling lama 6 (enam) bulan dan/atau denda paling sedikit Rp600.000,00 (enam ratus ribu rupiah) atau paling banyak Rp6.000.000,00 (enam juta rupiah)" kemudian dapat di uraikan bahwa di dalam Pasal 71, (1) di jelaskan bahwa Pejabat negara, pejabat daerah, pejabat aparatur sipil negara, anggota TNI/POLRI, dan Kepala Desa atau sebutan lain/Lurah dilarang membuat keputusan dan/atau tindakan yang menguntungkan atau merugikan salah satu pasangan calon.

Dari dua ketentuan diatas sangat jelas bahwa seorang Kepala Desa tidak dibolehkan melanggar ketentuan Pidana Pemilu tersebut yang di ikuti dengan sanksi pidana (Wahyuni 2017) yang jelas di dalam Undang-Undang Nomor 10 tahun 2016 tersebut. Begitu juga dalam hal pemilihan umum Kabupaten Indragiri Hilir yang terdiri dari 20 kecamatan 236 desa, potensi ini menjadi sangat mungkin karna tidak ada penghalang secara langsung yang menjadikan berpotensi masing-masing Kepala Desa mendapat tarik ulur pengaruh politik dari berbagai pasangan calon dan calon Legislatif dan berbagai kepentingan politik. Perlu kajian yang menyeluruh terkait potensi yang besar terjadinya pelanggaran baik secara administratif maupun pidana terkait Kepala Desa sebagai bagian dari subjek yang diatur di dalam perundang-undangan pemilihan umum maupun pemilihan kepala daerah.

Dengan banyaknya jumlah desa tersebut di Kabupaten Indragiri Hilir, menjadi kan potensi konflik kepentingan di dalam pemilu maupun terutama di dalam pemilihan kepala daerah menjadi sangat mungkin karena sangat logis seseorang akan memenangkan kontestasi politik di pemilihan kepala daera misalnya dengan mempengaruhi sebanyak-banyaknya kepala desa beserta perangkat-perangkatnya untuk menguntungkannya atau berpihak terhadap salah satu pasangan calon.

Terbukti khusus untuk pemilihan kepala daera di Kabupaten Indragiri Hilir menjadikan desa sebagai tolak ukur suksesnya Pilkada karena struktur dan juga kultur desa yang homogen sehingga sangat mudah dipengaruhi dalam kontestasi politik. Dengan cara mempengaruhi kepala desa dan perangkatnya sehingga pasangan calon dan tim sukses dapat mendapatkan suara masayarakatnya.

Sehingga potensi-potensi ini dikaitkan dengan ketentuan-ketentuan peraturan perundang-undangan yang ada diharapkan akan menjadi pendidikan politik bagi para kepala desa di Kabupaten Indragiri Hilir agar terhindar dari perbuatan-perbuatan yang melanggar ketentuan undang-undang yang memiliki sanksi administratif secara langsung terhadap kelangsungan jabatan kepala desanya termasuk ancaman sanksi pidana pemilihan baik dalam pemilihan umum maupun pemilihan kepala daerah

\section{MetOdologi PENELITIAN}

\subsection{Jenis Penelitian}

Tipe penelitian yang digunakan dalam penelitian adalah tipe penelitian hukum normatif yakni metode untuk menemukan suatu aturan hukum, prinsip-prinsip hukum, maupun doktrindoktrin hukum guna menjawab isu hukum yang dihadapi. Metode penelitian normatif menggunakan tiga pendekatan dalam penelitian, yaitu: pendekatan undang-undang (statute approach), pendekatan konseptual (conceptual approach), dan pendekatan historis (historical approach) (Peter, 2010).

\subsection{Sumber Penelitian Hukum}


Sumber penelitian hukum yakni bahan hukum primer dan bahan hukum sekunder. Bahan hukum primer merupakan bahan hukum yang bersifat autoritatif artinya mempunyai otoritas. Sedangkan bahanbahan sekunder berupa semua publikasi tentang hukum yang bukan merupakan dokumen-dokumen resmi.

\subsection{Analisis Data}

Seluruh data yang diperoleh dalam penelitian, dianalisis dengan menggunakan analisis kualitatif. Setelah itu dideskripsikan dengan menelaah permasalahan yang ada, menggambarkan, menguraikan hingga menjelaskan permasalahan-permasalahan yang berkaitan dengan penelitian tentang kajian hukum terhadap perangkat desa yang ikut serta dalam kampanye pemilu di kabupaten Indragiri Hilir.

\section{HASIL DAN PEMBAHASAN}

\subsection{Kajian Hukum Terhadap Kepala Desa Yang Ikut Serta Dalam Kampanye Pemilu Di Kabupaten Indragiri Hilir}

Sebagai negara yang menganut asas demokrasi, penting bagi warga Indonesia untuk memiliki sebuah proses untuk memilih orang untuk mengisi jabatan-jabatan politik tertentu. Proses tersebut kita kenal sebagai Pemilu atau Pemilihan umum. Pemilu menjadi penting karena pemilu merupakan instrumen penentu arah kebijakan publik satu Negara. Di Indonesia sendiri diketahui bahwa Pemilu presiden diadakan selama 5 tahun sekali, namun sebelum itu prosesnya sempat tidak seteratur sekarang. Pemilu di Indonesia dimulai sejak tahun 1955, 1955, 1971, 1977, 1982, 1987, 1992, 1997, 1999, 2004, 2009, 2014 dan 2019, terakhir 20202021 dengan demikian Indonesia sudah sangat lama mencoba berbagai formulasi untuk menjalankan asas demokrasi ini.(Rahmatunnisa, 2017)

Sejak pemilu pertama itu sebenarnya sudah banyak pula formulasi peraturan perundang-undangan tentang pemilu. Tercatat sudah banyak undang-undang atau peraturan pemilu ini Pengaturan pemilihan umum (selanjutnya disebut pemilu) di Indonesia telah mengalami perubahan dari waktu ke waktu, hal ini bertujuan adalah untuk meningkatkan kualitas demokrasi dan pemberdayaan masyarakat sebagai bentuk pencerminan kedaulatan rakyat. Perubahan pengaturan tentang pemilihan umum maupun pemilihan kepala daerah (selanjutnya disebut pilkada) baik yang berkaitan dengan hak-hak individu maupun perubahan dalam susunan kelembagaan. Penyelenggaraan pemilihan umum diharapkan harus bersih dari praktik-praktik kotor supaya menghasilkan perwakilan yang baik dan menjaga amanah masyarakat. Sebagaimana diketahui bahwa pemilihan umum legislatif yang lalu yang lalu masih terdapat berbagai pelanggaran penyelenggaraannya antara lain seperti permainan politik uang, pemaksaan, pengancaman, manipulasi data, balck campaingn dan sebagainya.(Spriyanto, 2017) Dengan demikian, praktik seperti ini perlu ditanggulangi karena sudah mengarah pada perbuatan pidana atau tindak pidana. Tindak pidana seperti ini sering disebut pidana pemilu, tetapi sebenarnya bukan hanya pidana pemilu melainkan secara lebih luas lagi disebut tindak pidana politik atau kejahatan politik.(Surbakti, 2014)(Endri, 2014)

Masalah hukum pemilu dalam konteks hukum pemilu merupakan hal yang sangat kompleks. Kedinamisan pengaturan pemilu dapat kita lihat dari proses perubahan undang-undangnya yang dinamis. Banyaknya pengaturan undang-undang tentang pemilu menjadikan masalah hukum pemilu menjadi masalah yang sulit diuraikan termasuk dalam persoalan penerapan pidana pemilu itu sendiri. Disamping kompleknya masalah, penyelengara atau lembaga yang terlibat masalah hukum pemilu juga banyak melibatkan lembaga.(Fahmi, 2015) Didalam Undang-Undang Nomor 8 Tahun 2012 Tentang Pemilu Anggota DPR, DPRD, DPD telah diakui 6 jenis masalah hukum pemilu yaitu; Pelangaran kode etik penyelengara pemilu, penyelengaraan administrasi pemilu, sengketa pemilu, tindak pidana pemilu, sengketa tata usaha Negara pemilu, dan perselisihan hasil pemilu. Kemudian di dalam Undang-Undang Nomor 1 Tahun 2015 Tentang Penetapan Perpu Nomor 1 Tahun 2014 menjadi Undang-Undang sebagaimana diubah dengan Undang-Undang Nomor 8 Tahun 2015 Tentang Pemilihan Gubernur, Bupati dan Walikota juga masih banyak terdapat Ketentuan Pidana Pemilu. (Fahmi, 2015)

Pemilu dalam konteksnya termasuk pilkada adalah merupakan sarana pelaksana keadaulatan rakyat di Indonesia yang juga dilaksanakan secara langsung, umum, bebas, rahasia, jujur dan adil dengan menjamin prinsip-prinsip keterwakilan, akuntabilitas dan legitimasi di dalam Negara kesatuan Republik Indonesia berdasarkan peraturan perundang-undangan yang berlaku. Disamping itu pemilu juga termasuk sarana pelaksanaan Hak Asasi Manusia 
(HAM) hak sebagai warga Negara dalam memilih para pemimpin bangsa tak terkecuali kepala daerah. Sehingga Negara perlu mengatur suatu aturan yang dapat menjamin segala hal yang menjadi tujuan dari pemilihan umum tersebut, salah satunya guna terlaksananya pemilu dan tercapainya tujuan dari pemilu tersebut maka Negara juga perlu mencantumkan sanksi berupa sanksi pidana didalam undang-undang pemilu termasuk undangundang pilkada.

Bahwa tujuan dilakukannya suatu pemilihan umum atau juga pemilihan kepala daerah (selanjutnya disebut Pemilukada) dalam suatu Negara adalah untuk mewujudkan pemerintahan yang baik, pada negara demokrasi tujuan ini tidak saja itu tapi juga untuk menjadikan atau untuk membentuk pemerintahan yang demokratis. Sehingga Dalam perspektif 'recruitment' kepala daerah pada Pasal 18 ayat (4) UUD Negara RI tahun 1945 hanya dilakukan 'secara demokratis' dan tidak menggunakan prinsip 'secara langsung' sebagaimana pemilihan Presiden dan Wakil presiden sebagaimana ditentukan dalam Pasal 6A ayat (1) UUD Negara RI Tahun 1945, tetapi melalui Pasal 56 ayat (1) UU No. 12 Tahun 2008 pemilihan kepala daerah tersebut dilaksanakan secara langsung seperti Pemilu anggota legislatif, Presiden dan Wakil Presiden.(Hoesein, 2010)Sejak berlakunya UU No. 32 Tahun 2004 tentang Pemerintahan Daerah, telah merubah sistem pemilihan Kepala Daerah dari pemilihan melalui DPRD menjadi pemilihan langsung oleh rakyat sebagaimana disebutkan dalam Pasal 56 ayat (1) yang berbunyi: "Kepala daerah dan wakil kepala daerah dipilih dalam satu pasangan calon yang dilaksanakan secara demokratis berdasarkan asas langsung, umum, bebas, rahasia, jujur, dan adil". Pada Pemilihan Kepala Daerah (Pemilukada), yang dilaksanakan dalam rentang waktu lima tahun merupakan suatu sarana untuk memilih kepala daerah yang berkualitas dan memiliki dedikasi. Hal ini penting, sebab melalui proses pemilukada akan menghasilkan seorang calon pemimpin dalam masa lima tahun ke depan untuk menentukan pembangunan di suatu daerah, baik itu tingkat provinsi maupun di kabupaten/kota. Pemilihan umum hampir tidak mungkin dilaksanakan tanpa kehadiran partai- partai politik di tengah masyarakat. Keberadaan partai juga merupakan salah satu wujud nyata pelaksanaan asas kedaulatan rakyat. Sebab dengan partaipartai politik itulah segala aspirasi rakyat yang kedaulatan berada di tangan rakyat, maka kekuasaan harus di bangun dari bawah.(Putra and Putra 2018)

Pemilihan umum tidak dapat terpisahkan oleh politik, karena pemilu merupakan alat kekuasaan untuk mencapai tujuan bersama. Pesta demokrasi yang berlangsung di Indonesia mulai dari pemilihan kepala daerah, pemilu legislatif dan pemilihan Presiden dan wakil Presiden secara langsung merupakan gambaran dari berjalannya sistem demokrasi di negara ini. Meskipun demikian proses demokrasi selama ini belum sepenuhnya menggambarkan masyarakat paham akan arti demokrasi. Masyarakat desa yang rata-rata masih berpendidikan rendah memahami politik hanya sebatas pesta rakyat yang dilakukan setiap lima tahun, dan tidak sedikitpartisipasi politik yang dilakukan masyarakat masih dipengaruhi oleh adanya gerakan-gerakan dari pihak-pihak yang berkuasa termasuk kepala desa.

Kepala Desa merupakan salah satu bagian dari Birokrasi Pemerintah yang mana telah diatur dalam Undang-Undang Pemilu, bahwa semua birokrasi pemerintahan tidak boleh terlibat atau mendukung salah satu calon, dan disini salah satunya adalah Kepala Desa yang diharapkan dapat mematuhi aturan Undang-Undang yang berlaku, namun dalam pelaksanaannya masih banyak seorang Kepala Desa menjadi pendukung bagi calon tertentu.Pada pasal 66 ayat 2 bagian C Peraturan Komisi Pemilihan Umum Nomor 7 tahun 2015 ditegaskan dalam kampanye, pasangan calon dan/atau tim kampanye dilarang melibatkan "kepala desa atau sebutan lain/lurah dan perangkat desa atau sebutan lain/kelurahan"

Larangan mengikut sertakan kepala desa dan perangkat desa terdapat dalam Pasal 280 ayat (2) Undang-Undang Pemilu yang berbunyi:

Pelaksana dan/atau tim kampanye dalam kegiatan kampanye pemilu dilarang mengikutsertakan:

a. Ketua, wakil ketua, ketua muda, hakim agung pada Mahkamah Agung, dan hakim pada semua badan peradilan di bawah Mahkamah Agung, dan hakim konstitusi pada Mahkamah Konstitusi;

b. Ketua, wakil ketua, dan anggota Badan Pemeriksa Keuangan;

c. gubernur, deputi gubernur senior, dan deputi gubernur Bank Indonesia;

d. direksi, komisaris, dewan pengawas dan karyawan badan usaha milik negara/badan usaha milik daerah; 
e. pejabat negara bukan anggota partai politik yang menjabat sebagai pimpinan di lembaga nonstruktural;

f. aparatur sipil negara;

g. anggota Tentara Nasional Indonesia dan Kepolisian Negara Republik Indonesia;

h. kepala desa;

i. perangkat desa;

j. anggota badan permusyawaratan desa; dan

k. Warga Negara Indonesia yang tidak memiliki hak memilih.

Pelanggaran terhadap larangan ketentuan di atas huruf $c$, huruf $f$, huruf $g$, huruf $i$, dan huruf $j$ merupakan tindak pidana pemilu. Pelanggaran atas larangan kampanye diancam dengan ketentuan Pidana sesuai Pasal 521 (lima ratus dua puluh satu) pada Pasal 280 ayat 1 (satu), setiap pelaksana, peserta pemilu, dan/atau tim kampanye dengan sengaja melanggar larangan Pelaksanaan Kampanye maka dikenakan pidana penjara paling lama 2 tahun dan denda paling banyak 24.000.000 (dua puluh empat juta rupiah) serta Pasal 523 (lima ratus dua puluh tiga) setiap pelaksana, peserta pemilu, dan/atau tim kampanye dengan sengaja menjanjikan atau memberikan uang atau materi lainnya sebagai sebagai imbalan kepada peserta pemilu baik secar langsung maupun tidak langsung dikenakan pidana penjara paling lama 2 tahun dan denda paling banyak 24.000.000 (dua puluh empat juta rupiah).

Jelas bahwa apabila dalam kampanye melibatkan dan perangkat desa termasuk dalam pelanggaran pemilu dan masuk dalam tindak pidana pemilu.

Di Kabupaten Indragiri Hilir ada sekitar 20 kecamatan yang terdiri dari 236 desa, hal ini menjadikan kepala desa menjadi sangat rawan untuk terlibat kampanye maupun upaya menguntungkan atau merugikan salah satu pasangan calon dalam konteks pemilihan kepala daerah misalnya.

Tabel 1. Kecamatan di Indragiri Hilir dan jumlah TPS.

\begin{tabular}{|l|l|l|l|}
\hline No. & Kecamatan & TPS & DPT \\
\hline 1. & Batang Tuaka & 63 & 18.154 \\
\hline 2. & Concong & 35 & 8.619 \\
\hline 3. & Enok & 97 & 24.735 \\
\hline 4. & Gaung & 81 & 26.285 \\
\hline 5. & Gaung Anak Serka & 57 & 15.189 \\
\hline 6. & Kateman & 109 & 25.117 \\
\hline
\end{tabular}

\begin{tabular}{|l|l|l|l|}
\hline 7. & Kempas & 75 & 25.500 \\
\hline 8. & Kemuning & 69 & 22.808 \\
\hline 9. & Keritang & 155 & 42.984 \\
\hline 10. & Kuala Indragiri & 47 & 10.893 \\
\hline 11. & Mandah & 101 & 28.074 \\
\hline 12. & Pulau Burung & 55 & 11.917 \\
\hline 13. & Pelagiran & 104 & 21.552 \\
\hline 14. & Rateh & 108 & 27.794 \\
\hline 15. & Sungai Batang & 29 & 7.734 \\
\hline 16. & Tanah Merah & 66 & 17.396 \\
\hline 17. & Teluk Belengkong & 27 & 6.678 \\
\hline 18. & Tembilahan & 154 & 47.056 \\
\hline 19. & Tembilahan Hulu & 79 & 28.500 \\
\hline 20. & Tempuling & 68 & 21.007 \\
\hline
\end{tabular}

(Hasil Rapat Pleno KPU Kabupaten Indragiri Hilir)

Pemilihan umum Bupati Indragiri Hilir 2018 (selanjutnya disebut Pilbup Inhil 2018) dapat kita lihat telah dilaksanakan pada 27 Juni 2018 lalu untuk menentukan Bupati dan Wakil Bupati Indragiri Hilir periode 20182023. Ini merupakan pemilihan kepada daerah ketiga bagi Indragiri Hilir yang dilakukan secara langsung menggunakan sistem pencoblosan. Jadwal pemilihan ini mengikuti jadwal pilkada serentak gelombang ketiga pada Juni 2018.

Dalam pemilihan umum Bupati Indragiri Hilir ini ada 3 pasangan calon yang salah satunya adalah Petahan.

4.2. Gambaran Perolehan Suara Pemilihan Umum Bupati Indragiri Hilir Tahun 2018.

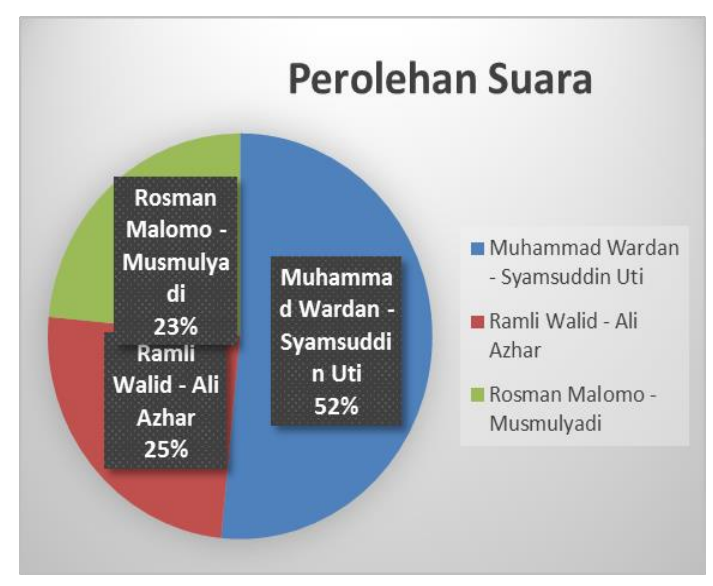

Gambar 1. Grafik Perolehan Suara Masingmasing Paslon. 
Dari grafik di atas dapat Kita lihat bahwa sangat jauh lebih besar perolehan suara pasangan calon Muhammad Wardan yaitu 50 persen lebih, selama penyelengaraan pemilihan Bupati Indragiri Hilir memang tidak terjadi pelangaran aturan terkait keterlibatan kepala desa sebagai bagian dari penyelengara negara sebagaimana diatur di dalam ketentuan yang diuraiakn diatas. Perlu kita sikapi potensi-potensi yang mungkin terjadi di pemilihan umum yang akan datang yang akan di selengarakan di Kabupaten Indragiri Hilir, yaitu Pemilihan Umum Kepala Daerah yang akan diselengarakan pada tahun 2024 mendatang.

Secara garis besar pelangaran dalam tahapan pemilihan kepala daerah secara langsung dapat di klasifikasikan menjadi 3 (tiga) pelanggaran, yaitu pelangaran administratif, pelangaran pidana, dan perselisihan hasil pemilihan umum. Ketiga potensi pelangaran tersebut bisa menjadi mungkin seorang kepala desa terseret dalam pusaran politik di daerah yang berdampak pada terselengaranya pemilihan kepela daerah yang tidak sehat. Meskipun undangundang pemerintahan daerah sebagai aturan payung dari Undang-undang Nomor 10 Tahun 2016 adakalanya memang pelangaran dalam pemilihan umum kepala daerah yang terjadi hanya pelangaran administratif saja akan tetapi selain pelangaran administratif terjadi pelangaran pidana pemilihan sebagaimana diatur di dalam ketentuan pidana Undang-undang.(Parlindungan 2019)

Terhadap pelangaran administrasi pemilu sesungguhnya Undang-undang tidak memberikan batasan yang terlalu jelas karena yang di defenisikan dengan pelangaran administrasi adalah pelangaran terhadap semua aturan dan atau persyaratan yang di tasbihkan di dalam peraturan perundang-undangan. keluasan defenisi tersebut membuat pengawas pemilu yaitu Badan Pengawas pemilihan Umum (Bawaslu) mendefenisikan pelangaran administrasi sebagai pelangaran terhadap ketentuan dan persyaratan yang kemudian menjadi subjek pengaturan di dalam undang-undang dan ketentuan-ketentuan lainya yang dibuat oleh penyelengara pemilu sendiri, sehingga dapat pula dikatakan bahwa pelangaran diluar ketentuan pidana di dalam undang-undang disebut sebagai pelangaran administrasi. dalam konteks ini hanya pelangaran dalam perundangundangan pemilu misalnya dalam Undangundang Nomor 10 tahun 2016 jo Undangundang Nomor 1 tahun 2015 tentang Pemerintahan daerah yang ada ketentuan pidana pemilunya dapat dikatan sebagai pelangaran pidana pemilihan kepala daerah, adapan pelangaran terhadap aturan bawaslu dan KPU, jelas sebagai pelangaran administratif saja karena tidak ada ketentuan pidananya. Ketentuan-ketentuan dalam KUHP dan aturan hukum pidana lain di luar itu belum bisa juga dikatakan sebagai pidana pemilihan dikarenakan karena tidak mengatur tentang pemilu.

Sedangan yang dapat didefenisikan sebagai pidana pemilihan atau pidana pemilu sebenarnya undang-undang juga tidak mengartikannya secara rinci,(Fahmi 2019) namun jika kita defenisikan dapat kita jelaskan bahwa pidana pemilihan atau pidana pemilu adalah segala ketentuan pidana yang terdapat di dalam peraturan perundang-undangan yang mengatur tentang pemilihan umum termasuk pemilihan kepala daerah, pemilihan legislatif dan pemilihan peresiden dan wakil presiden. Dalam terminologi hukum pidana tidak ada juga defenisi baku utuh tentang pidana pemilu atau pidana pemilihan sehingga penulis sendiri memandang lebih tepat bila disebut tidak pidana pemilu.

Dalam persoalan kepala desa sebagai subjek hukum yang diatur di dalam undangundang kepeliluan ada beberapa aspek yang perlu diperhatikan yang pertama ada kemungkinan kepala desa bersingungan dengan ketentuan perundang-undangan yang diancap sanksi administratif ada ketentuan juga tentang objek perbuatan yang diatur terhadap kepala desa dan perangkat desa yang diancam dengan sanksi pidana atau termasuk tindak pidana pemilu.(Fahmi 2016)

Oleh karena itu perlu netralitas kepala desa termasuk selaga perangkat desa sebagai penyelengara kekuasaan negara terkecil dalam kontes penyelengara pemerintahan di desa.(Fauzi 2019) tolak ukur netral penyelengara negara itu sebagaimana yang diatur undang-undang secara normatif.

\section{KESIMPULAN DAN SARAN}

Seseorang Kepala Desa yang tidak memihak dan menunjukan keadaan atau sikap independen terhadap kondisi yang di perhadapkan kepadanya. Dalam Pasal 29 Undang-Undang Nomor 6 Tahun 2014 dinyatakan bahwa kepala desa harus netral dari pengaruh semua golongan dan partai politik, tidak diskriminatif dalam memberikan pelayanan kepada masyarakat, dan dilarang menjadi anggota dan pengurus partai politik. 
Bersikap netral menjelang perhelatan pesta demokrasi pemilukada, tentu tidak ditujukan semata pada pejabat yang berencana mencalonkan kembali atau dengan istilah lain incumbent. Tapi suatu hal yang perlu dupahami bahwa seorang kepala desa harus mampu menempatkan diri sebagai pelayan masyarakat, bukan melayani kepentingan pribadi orang per orang dan atau calon tertentu. Penyelenggaraan tugas pemerintahan dan pembangunan nasional tergantung pada kesempurnaan aparatur negara khususnya kepala desa. Dengan demikian, dalam rangka mencapai tujuan pembangunan nasional yakni mewujudkan masyarakat madani yang taat hukum, berperadaban modern, demokratis, makmur, adil, dan bermoral tinggi, diperlukan kepala desa yang bertugas sebagai abdi masyarakat yang harus menyelenggarakan pelayanan secara adil dan merata kepada masyarakat dengan dilandasi kesetiaan dan ketaatan kepada pancasila dan Undang-Undang Dasar 1945

Pentingnya menjaga netralitas juga semestinya dijadikan sebagai suatu paham yang harus di junjung tinggi agar misi yang bersangkutan sebagai pelayan masyarakat tak terkontaminasi dengan kepentingan yang fragmatis. Ini tentu harus dipahami dan betul-betul dijaga oleh semua kepala desa agar tidak membuat sikap dan perilaku blunder. Dengan adanya keberpihakan suatu oknum pemerintahan dalam penyelenggaraan pemilihan kepala daerah merupakan suatu bentuk dari ketidakadilan dalam Pemilu, dan bertentangan dengan hukum sehingga masuk dalam pelangaran administrasi pemilihan maupun tindak pidana pemilu yang berujung kepada pidana.

\section{UCAPAN TERIMA KASIH}

Alhamdulillah, puji dan syukur kepada Allah SWT atas segala kanurian dan nikmat Nya kepada peneliti sehingga penelitian ini dapat diselesaikan oleh peneliti. Untuk itu peneliti juga mengucapkan terima kasih kepada pihak-pihak yang telah memberikan bantuan baik secara materil maupun formil yaitu kepada Rektor Universitas Islam
Indragiri, rekan dosen di Prodi Magister Hukum, Fakultas Hukum, Universitas Borneo Tarakan, Kalimantan Utara yang bersama menyelesaikan penelitian ini dan kepada seluruh pihak yang tak dapat disebutkan namanya satu persatu. Semoga karya ini bermanfaat dan menambah wawasan. Amin

\section{DAFTAR PUSTAKA}

[1]. Fahmi, Khairul. 2016. "Sistem Penanganan Tindak Pidana Pemilu." Jurnal Konstitusi 12(2): 264-83.

[2]. - - . 2019. "Sistem Keadilan Pemilu Dalam Penanganan Pelanggaran Dan Sengketa Proses Pemilu Serentak 2019 Di Sumatera Barat."

[3]. Fauzi, Achmad. 2019. "Otonomi Daerah Dalam Kerangka Mewujudkan Penyelenggaraan Pemerintahan Daerah Yang Baik." Jurnal Spektrum Hukum 16(1): 119-36.

[4]. Harry Setiawan. 2013. "Ir Perpustakaan Universitas Airlangga Tesis Ir - Perpustakaan Universitas Airlangga." : 1-8.

[5]. Ii, B A B. 2012. "Lijan Poltak Sinambela. 2012. Kinerja Pegawai: Teori, Pengukuran Dan Implikasi. Yogyakarta: Graha Ilmu." : 2012.

[6]. Parlindungan, Ahmad. 2019. "Analisis Penegakan Hukum Terhadap Tindak Pidana Politik Uang Dalam Pemilihan Kepala Daerah Ditinjau Dari UndangUndang Nomor 10 Tahun 2016." Journal of Education, Humaniora and Social Sciences (JEHSS) 2(2): 335-51.

[7]. Putra, Hermansyah, and Hermansyah Putra. 2018. "Mendorong Transparansi Dan Akuntabilitas Dana Kampanye Pada Penyelenggaraan Pilkada Serentak Tahun 2018." JPPUMA Jurnal IImu Pemerintahan dan Sosial Politik Universitas Medan Area 6(2): 112-21.

[8]. Wahyuni, F. 2017. "Dasar-Dasar Hukum Pidana Di Indonesia." Nusantara Persada Utama. 